\title{
The effect of bilateral internal thoracic artery harvesting on superficial and deep sternal infection: The role of skeletonization
}

\author{
Ruggero De Paulis, MD \\ Stefano de Notaris, $\mathrm{MD}^{\mathrm{a}}$ \\ Raffaele Scaffa, MD ${ }^{a}$ \\ Saverio Nardella, $\mathrm{MD}^{\mathrm{a}}$ \\ Jacob Zeitani, MDa \\ Costantino Del Giudice, MD \\ Alfonso Penta De Peppo, MD \\ Fabrizio Tomai, MD ${ }^{\mathrm{a}}$ \\ Luigi Chiariello, MD
}

From the Division of Cardiac Surgery, University of Rome Tor Vergata, Rome, Italy, ${ }^{\text {a }}$ and Second University of Naples, ${ }^{\mathrm{b}}$ Italy.

Received for publication June 16, 2004; revisions received July 22, 2004; accepted for publication July 26, 2004.

Address for reprints: Ruggero De Paulis, MD, Cattedra di Cardiochirurgia, Università di Roma Tor Vergata, European Hospital, via Portuense 700, 00149 Roma, Italy (E-mail: depauli@tin.it).

J Thorac Cardiovasc Surg 2005;129:536-43 $0022-5223 / \$ 30.00$

Copyright $\odot 2005$ by The American Association for Thoracic Surgery

doi:10.1016/j.jtcvs.2004.07.059
Objective: To determine the relative risk of sternal dehiscence in patients undergoing bilateral internal thoracic artery harvesting and to assess whether and to what extent the technique of artery skeletonization might reduce this risk.

Methods: Prospectively collected data on patients undergoing coronary artery bypass operations with at least a single internal thoracic artery were reviewed. The last 450 patients receiving bilateral internal thoracic artery grafts were compared with 450 patients who received a single internal thoracic artery during the same period. The left internal thoracic artery was always harvested in a pedicled fashion. Among patients receiving a bilateral internal thoracic artery, both arteries were harvested in a pedicled fashion in 300 cases, whereas both internal thoracic arteries were skeletonized in the remaining 150 cases.

Results: Compared with a single internal thoracic artery, harvesting both internal thoracic arteries either in a skeletonized or in a pedicled fashion increased the chance of deep $(1.1 \%$ vs $3.3 \%$ vs $4.7 \% ; P=.01)$ or superficial $(4.8 \%$ vs $7.8 \%$ vs $12 \% ; P=.002)$ sternal infection. However, the technique of artery harvesting (odds ratio, 4.1 ; 95\% confidence interval, 1.4-12.1); the presence of peripheral arteriopathy (odds ratio, 3.1; 95\% confidence interval, 1.2-8.5), and resternotomy for bleeding (odds ratio, 8.2; 95\% confidence interval, 2.0-33.6) were the only independent predictors for deep sternal infection, whereas the technique of artery harvesting (odds ratio, 3.0; 95\% confidence interval, 1.6-5.4), female sex (odds ratio, 2.2; 95\% confidence interval, 1.2-4.2), and diabetes (odds ratio, 1.7; 95\% confidence interval, 1.0-2.9) were the only independent predictors of superficial sternal infection. In diabetic patients, there was no difference in the incidence of deep sternal infection among patients receiving a single internal thoracic artery or double skeletonized internal thoracic arteries $(P=.4)$.

Conclusions: Bilateral internal thoracic artery harvesting carries a higher risk of sternal infection than harvesting a single internal thoracic artery. Skeletonization of both internal thoracic arteries significantly decreases this risk. A strategy of bilateral thoracic artery grafting can also be offered to patients at high risk for wound infection. 


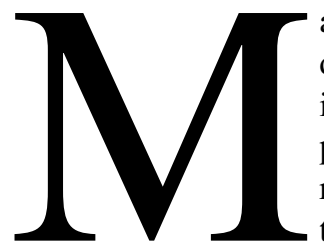

any years have been necessary to demonstrate that the use of bilateral internal thoracic arteries (BITA) improves survival, reduces the need for repeat revascularization, and reduces the incidence of recurrent angina when compared with the use of a single internal thoracic artery (SITA). ${ }^{1-5}$ Given the continuing improvements in the results of percutaneous transluminal angioplasty with the use of drug-eluting stents, patients referred to surgery should not be denied the benefit of receiving 2 or more coronary bypass grafts by means of 2 internal thoracic arteries (ITAs). The drawbacks of an extensive use of BITAs include a higher incidence of sternal infection or dehiscence associated with the decrease in sternal blood flow. ${ }^{6,7}$ This is particularly important in patients already at high risk for sternal infection, such as those with diabetes, obesity, chronic pulmonary obstructive disease, or diffuse arteriopathy. ${ }^{8-11}$ More often, these types of patients are revascularized by means of a SITA plus venous conduits or alternative arterial conduits. $^{12}$

Recently, the technique of skeletonization of the thoracic artery at the time of harvesting has been proposed as a possible way to reduce the incidence of sternal infection while maintaining the benefit of using both ITAs. ${ }^{13-19}$ This study aimed to determine the increased risk of sternal dehiscence and infection in patients receiving BITA grafts and to assess the merit of artery skeletonization in reducing such risk.

\section{Patients and Methods}

The last 450 patients undergoing BITA grafting at the University of Tor Vergata, Rome, and an equal number of patients undergoing SITA grafting during the same period were compared. Given the larger number of patients available in the SITA group (approximately 1800), they were selected on the basis of the same day (2 days before or after) of the operation as BITA patients. Patients with other concomitant procedures were excluded. Institutional ethics approval was obtained. Patients who received a SITA were compared with those who received BITA with respect to their incidence of superficial or deep sternal dehiscence or infection. All patients received the same skin preparation, scrub of the surgical sites, and cephalosporin antibiotic administration before skin incision (1 $\mathrm{g}$ of cefuroxime or ceftizoxime).

Within the BITA group, 300 patients had both ITAs harvested in a pedicled fashion, whereas in the remaining 150 patients, both conduits were skeletonized. A single left ITA was always harvested in a pedicled manner, along with the accompanying veins, fascia, and a small strip of muscle, with electrocautery only. Only saphenous veins were used as additional conduits. The decision of whether to harvest both ITAs in a skeletonized fashion was left to the attending surgeon, and harvesting was performed either by the attending surgeon or by the residents. The 2 types of harvesting techniques were concurrent rather than sequential cohorts so that any confounding effect of the date of operation could be avoided.
TABLE 1. Preoperative characteristics of patients who received bilateral (BITA) or single (SITA) left internal thoracic arteries

\begin{tabular}{lccc}
\hline Variable & $\begin{array}{c}\text { BITA } \\
\text { (n }=450)\end{array}$ & $\begin{array}{c}\text { SITA } \\
\text { (n = 450) }\end{array}$ & $\boldsymbol{P}$ value \\
\hline Age (y) & $56.2 \pm 10.3$ & $62.1 \pm 8.5$ & $<.0001$ \\
Sex (M/F) & $399 / 51$ & $380 / 70$ & .06 \\
Emergency timing & $4(0.8 \%)$ & $2(0.4 \%)$ & .41 \\
Urgent timing & $28(6.2 \%)$ & $27(6 \%)$ & .88 \\
Hypertension & $167(37 \%)$ & $182(40 \%)$ & .20 \\
NYHA class & $1.5 \pm 0.8$ & $1.5 \pm 0.8$ & .42 \\
CCS class & $2.5 \pm 1.1$ & $2.4 \pm 1.1$ & .78 \\
LVEF (\%) & $53 \pm 11$ & $52 \pm 10$ & .19 \\
CAD (no. vessels) & $2.8 \pm 0.4$ & $2.7 \pm 0.5$ & .0002 \\
Creatinine $>1.5 \mathrm{mg} / \mathrm{dL}$ & $35(7.7 \%)$ & $13(2.8 \%)$ & .001 \\
PVD & $64(14.2 \%)$ & $59(13.1 \%)$ & .6 \\
Type 2 DM & $131(29.1 \%)$ & $124(27.5 \%)$ & .59 \\
Type 2 DM + PVD & $39(8.6 \%)$ & $29(6.4 \%)$ & .2 \\
COPD & $72(16 \%)$ & $24(5.3 \%)$ & $<.0001$ \\
BMI (kg/m ${ }^{2}$ ) & $27 \pm 3.5$ & $27.6 \pm 12$ & .3 \\
Obesity (>30 kg/m $\left.{ }^{2}\right)$ & $78(17.3 \%)$ & $92(20.4 \%)$ & .23 \\
Reoperation & $5(1.1 \%)$ & $5(1.1 \%)$ & .99 \\
Preoperative stay (d) & $4.2 \pm 3.2$ & $4.4 \pm 3.1$ & .41 \\
\hline
\end{tabular}

NYHA, New York Heart Association; CCS, Canadian Cardiovascular Society; $L V E F$, left ventricular ejection fraction; $C A D$, coronary artery disease; $P V D$, peripheral vascular disease (carotid/aortoiliac/femoral); $D M$, diabetes mellitus; $C O P D$, chronic obstructive pulmonary disease; $B M I$, body mass index.

TABLE 2. Intraoperative characteristics of patients who received bilateral (BITA) or single (SITA) left internal thoracic arteries

\begin{tabular}{lccr}
\hline Variable & $\begin{array}{c}\text { BITA } \\
(\mathbf{n}=\mathbf{4 5 0})\end{array}$ & $\begin{array}{c}\text { SITA } \\
(\mathbf{n}=\mathbf{4 5 0 )}\end{array}$ & $\boldsymbol{P}$ value \\
\hline No. bypass grafts & $3.2 \pm 0.7$ & $3 \pm 0.8$ & .0002 \\
Crossclamp time (min) & $54 \pm 18$ & $49 \pm 15$ & $<.0001$ \\
CPB time (min) & $82 \pm 27$ & $85 \pm 26$ & .25 \\
Free RITA grafts & $100(22.1 \%)$ & - & -
\end{tabular}

$C P B$, Cardiopulmonary bypass; RITA, right internal thoracic artery.

Skeletonization of both conduits was usually reserved for patients at a perceived increased risk for sternal infection because of the presence of 1 or more risk factors, including diabetes, peripheral vascular disease, chronic obstructive pulmonary disease, obesity, chronic renal insufficiency, and advanced age (Table 1).

Skeletonized ITAs were dissected from the adjacent veins and muscle, and the arterial branch was sutured with hemoclips and divided with small scissors. Both pedicled and skeletonized ITAs were harvested from their distal bifurcation up to $1 \mathrm{~cm}$ from their emergence from the subclavian arteries, whether they were used as an in situ graft or a free graft. The ITAs were divided 3 minutes after systemic heparinization and left in a sponge soaked with papaverine while the distal end was clamped with a small bulldog clamp. The pleural spaces were always opened, and the pericar- 
TABLE 3. Postoperative characteristics of patients who received bilateral (BITA) or single (SITA) left internal thoracic arteries

\begin{tabular}{lccc}
\hline Variable & $\begin{array}{c}\text { BITA } \\
(\mathbf{n}=\mathbf{4 5 0})\end{array}$ & $\begin{array}{c}\text { SITA } \\
(\mathbf{n}=\mathbf{4 5 0})\end{array}$ & $\boldsymbol{P}$ value \\
\hline Hospital death & $2(0.4 \%)$ & 0 & .15 \\
Stroke & 0 & 0 & - \\
Low-output syndrome & $2(0.4 \%)$ & $3(0.6 \%)$ & .5 \\
Bleeding (mL) & $942 \pm 438$ & $800 \pm 384$ & $<.0001$ \\
RBC transfusion (U) & $1.2 \pm 1.9$ & $1.1 \pm 1.7$ & .5 \\
Resternotomy for bleeding & $12(2.6 \%)$ & $10(2.2 \%)$ & .65 \\
ICU stay (d) & $2.1 \pm 0.6$ & $2.1 \pm 0.6$ & .37 \\
Postoperative stay (d) & $6.4 \pm 2.3$ & $6.9 \pm 4$ & .03 \\
Follow-up (mo) & $34.4 \pm 31$ & $35.71 \pm 31$ & .51 \\
Overall mortality & $5(1.1 \%)$ & $4(0.8 \%)$ & .71 \\
\hline
\end{tabular}

$R B C$, Red blood cell; ICU, intensive care unit.

dium was incised to avoid any tension on the arterial conduits. Chest drains were positioned in both pleural spaces and in the mediastinum. The sternum was closed with a single stainless-steel wire for each $10 \mathrm{~kg}$ of body weight. The subcutaneous tissues and skin were closed with absorbable sutures.

The presence of superficial or deep sternal infection was diagnosed either at the time of hospitalization or during the first 2 months after discharge. Definitions for deep and superficial sternal wound infection followed the guidelines of the Centers for Disease Control and Prevention. ${ }^{20}$ Deep infection was considered in case of 1 of the following findings: isolation of an organism from culture of the mediastinal tissue or fluid, visual evidence of mediastinitis, chest instability, or fever associated with the presence of purulent drainage. Superficial sternal infection was defined when purulent discharge was not associated with involvement of sternal or mediastinal tissues.

The Student $t$ test was used to compare continuous data among groups. Nonparametric data were compared by using the $\chi^{2}$ test or the Fisher exact test, as appropriate. Stepwise logistic regression was used to identify independent predictors of sternal infection in the groups considered. Continuous data are indicated as mean \pm SD. Categoric data are expressed as percentages. All statistical analysis was performed with StatView (version 5.0) for Windows 8.0 (SAS Institute Inc, Cary, NC).

\section{Results}

Patients in the groups receiving SITA or BITA grafts were similar for most preoperative variables. Patients in the BITA group were slightly younger and had a higher incidence of chronic obstructive pulmonary disease and renal insufficiency (Table 1). The intraoperative variables were similar between the 2 groups; the number of grafts was slightly higher in patients receiving 2 ITAs, and, accordingly, the length of crossclamp time was an average of 5 minutes longer (Table 2). Total mortality (operative plus late mortality) was approximately $1 \%$ in both groups; postoperative bleeding was higher in patients receiving BITA (Table 3). Compared with patients receiving bilateral pedicled ITAs,
TABLE 4. Preoperative characteristics of patients who received skeletonized or pedicled bilateral internal thoracic arteries (BITA)

\begin{tabular}{lccc}
\hline Variable & $\begin{array}{c}\text { Skeletonized } \\
\text { BITA } \\
(\mathbf{n}=\mathbf{1 5 0})\end{array}$ & $\begin{array}{c}\text { Pedicled } \\
\text { BITA } \\
(\mathbf{n}=\mathbf{3 0 0})\end{array}$ & $\boldsymbol{P}$ value \\
\hline Age (y) & $60.4 \pm 10.2$ & $54.1 \pm 9.7$ & $<.0001$ \\
Sex (M/F) & $125 / 25$ & $274 / 26$ & .01 \\
LVEF (\%) & $54 \pm 10$ & $53 \pm 10$ & .29 \\
Creatinine $>1.5 \mathrm{mg} / \mathrm{dL}$ & $15(9.9 \%)$ & $20(6.6 \%)$ & .0019 \\
PVD & $32(21.1 \%)$ & $32(10.7 \%)$ & .011 \\
Type 2 DM & $59(39 \%)$ & $72(24 \%)$ & .0042 \\
COPD & $29(19.2 \%)$ & $43(14.3 \%)$ & $<.0001$ \\
Type 2 DM + PVD & $22(14.5 \%)$ & $17(5.6 \%)$ & .04 \\
BMI $\left(\mathrm{kg} / \mathrm{m}^{2}\right)$ & $27 \pm 3.5$ & $27 \pm 3.5$ & .9
\end{tabular}

$L V E F$, Left ventricular ejection fraction; $P V D$, peripheral vascular disease (carotid/aortoiliac/femoral); $D M$, diabetes mellitus; COPD, chronic obstructive pulmonary disease; $B M I$, body mass index.

those receiving bilateral skeletonized ITAs had a higher incidence of all major risk factors, with the exception of a similar body mass index (Table 4).

Patients receiving a SITA graft had a lower incidence of deep sternal infection than those receiving BITA grafts $(1.1 \%$ vs $4.2 \%$; $P=.004$; Figure 1$)$. Among the BITA group, those receiving skeletonized ITAs had a lower, albeit not significant, incidence of infection than patients receiving pedicled ITAs (3.3\% vs $4.7 \%, P=.4$; Figure 1 , inset). Similarly, patients receiving a SITA had significantly less superficial sternal infection compared with those receiving skeletonized or pedicled bilateral ITAs $(4.8 \%$ vs $7.8 \%$ and $12 \% ; P=.002$; Figure 2). Considering only patients with diabetes (total number of 255), the incidence of deep sternal infection was similar between patients receiving single or double skeletonized ITAs ( $1.6 \%$ vs $3.5 \% ; P=.4)$, but it was significantly higher in patients receiving double pedicled ITAs $(12.5 \% ; P<.01$ vs other groups). Of note, a significant difference among diabetic and nondiabetic patients was evident only in those receiving bilateral pedicled ITAs (Figure 3).

We then performed a multivariate analysis to identify independent predictors of deep and superficial sternal infection in all groups of patients. Harvesting 2 ITAs (odds ratio, 3.4; 95\% confidence interval [CI], 1.2-9.7), the presence of peripheral arteriopathy (odds ratio, 3.1; 95\% CI, 1.2-8.5), and resternotomy for bleeding (odds ratio, 8.2; 95\% CI, 2.0-33.6) were the only independent predictors for deep sternal infection. However, when the technique of harvesting was inserted into the regression analysis, a double pedicled artery, but not a double skeletonized artery, was still an independent predictor of deep sternal infection (odds ratio, 4.1; 95\% CI, 1.4-12.1; Figure 4). 


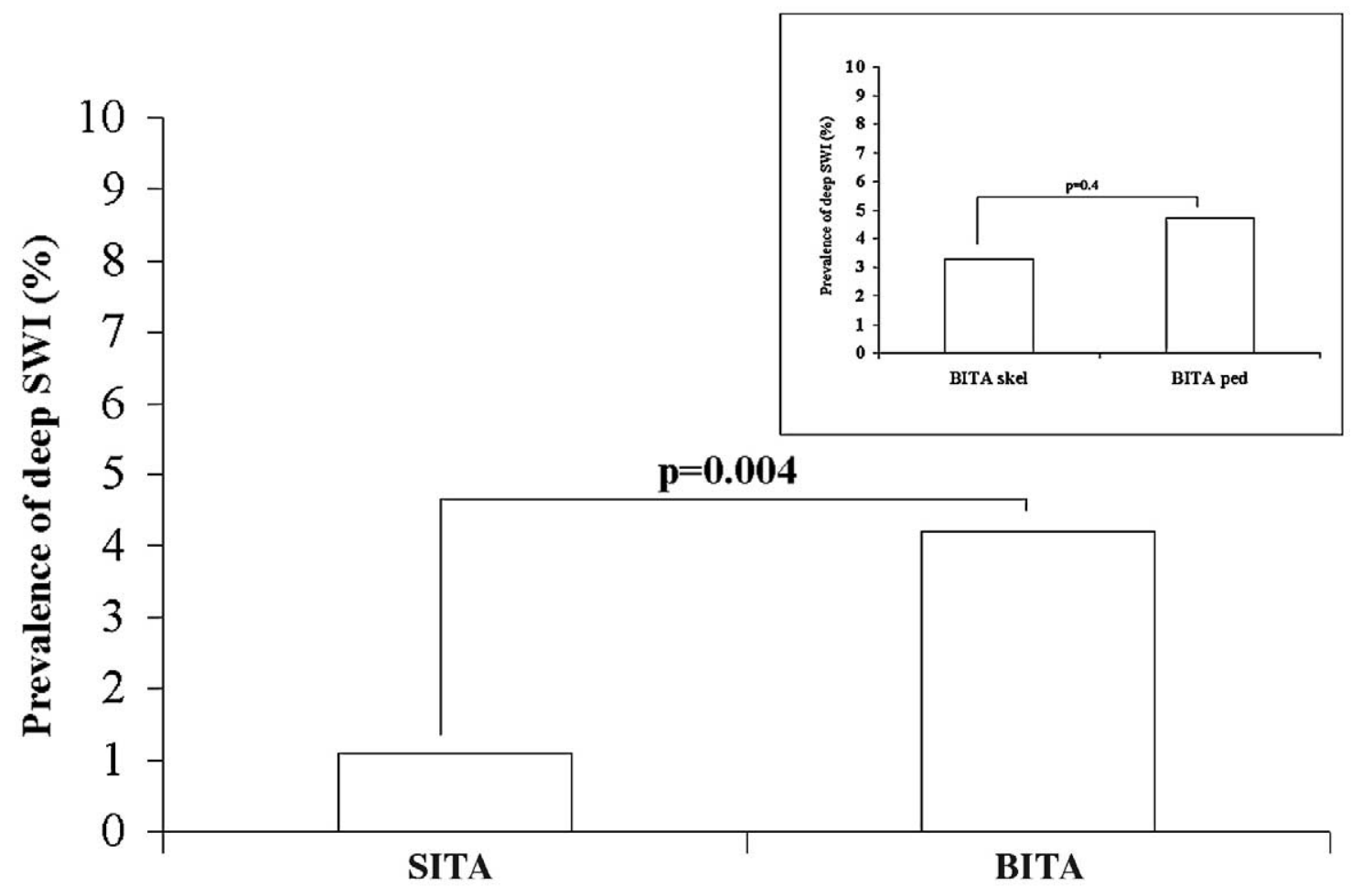

Figure 1. Prevalence of deep sternal wound infection (SWI) in patients receiving single (SITA) or bilateral (BITA) internal thoracic arteries. Differences among skeletonized or pedicled BITAs are shown in the inset.

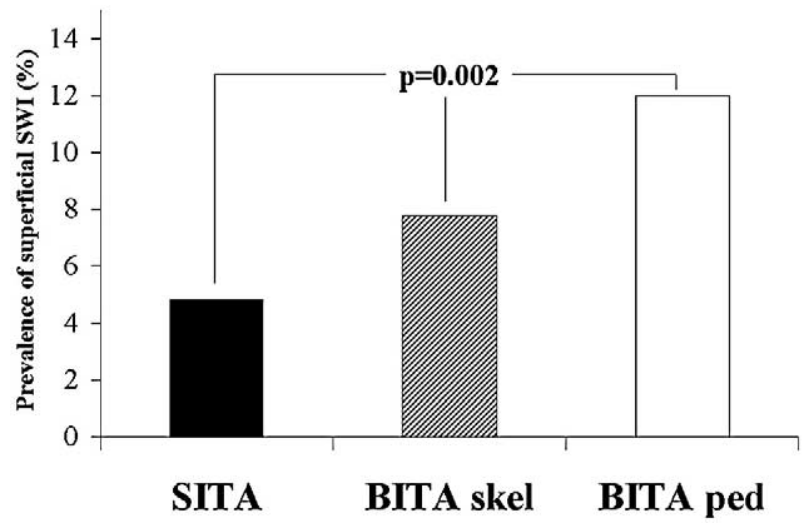

Figure 2. Prevalence of superficial sternal wound infection (SWI) in patients receiving single (SITA), bilateral skeletonized (BITA skel), or bilateral pedicled (BITA ped) internal thoracic arteries.

Harvesting 2 ITAs (odds ratio, 2.4; 95\% CI, 1.4-4.2), the presence of diabetes (odds ratio, 1.7; 95\% CI, 1.0-2.9), and female sex (odds ratio, 2.2; 95\% CI, 1.2-4.2) were the only independent predictors for superficial sternal infection. Similarly, when the technique of harvesting was inserted into

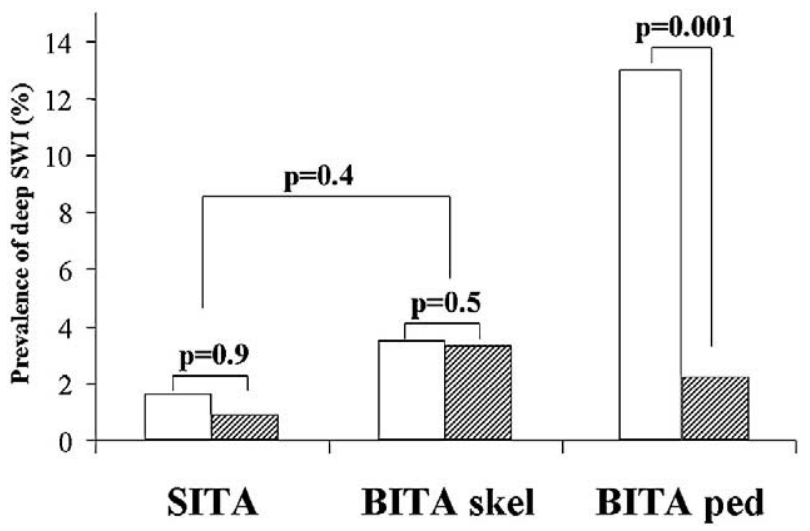

Figure 3. Prevalence of deep sternal wound infection (SWI) in patients with (white column) and without (gray column) diabetes receiving single (SITA), bilateral skeletonized (BITA skel), or bilateral pedicled (BITA ped) internal thoracic arteries.

the regression analysis, a double pedicled artery, but not a double skeletonized artery, was still an independent predictor of superficial sternal infection (odds ratio, 3.0; 95\% CI, 1.6-5.4; Figure 5). 


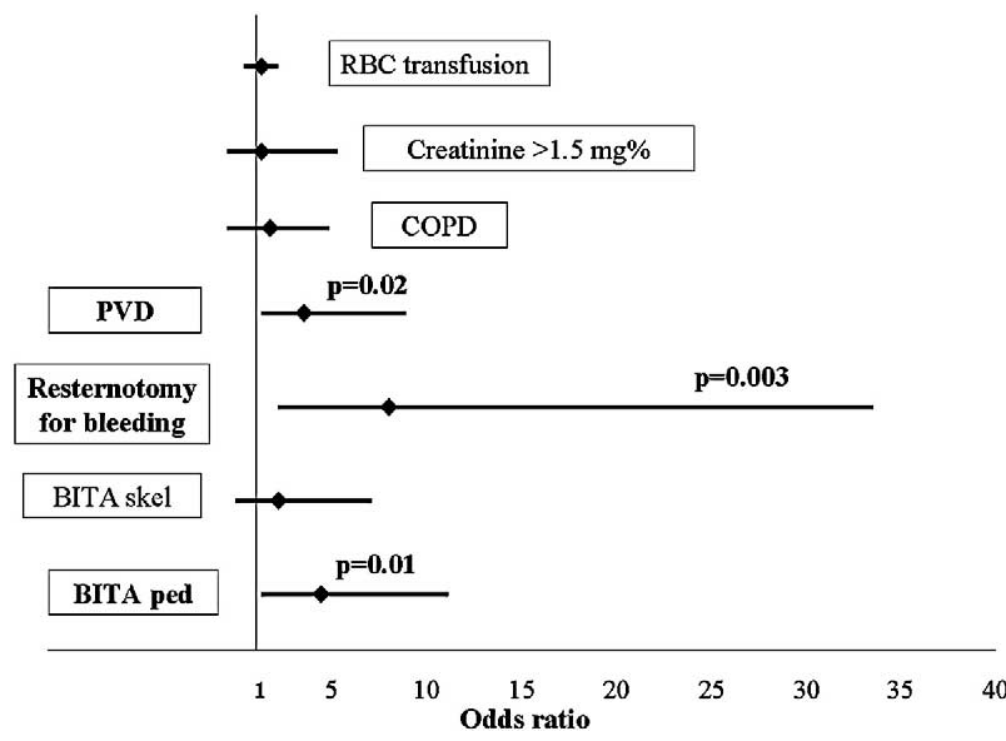

Figure 4. Odd ratios for the most significant risk factor in determining the risk of deep sternal wound infection. RBC, Red blood cell; COPD, chronic obstructive pulmonary disease; PVD, peripheral vascular disease; BITA skel, bilateral skeletonized internal thoracic arteries; BITA ped, bilateral pedicled internal thoracic arteries.

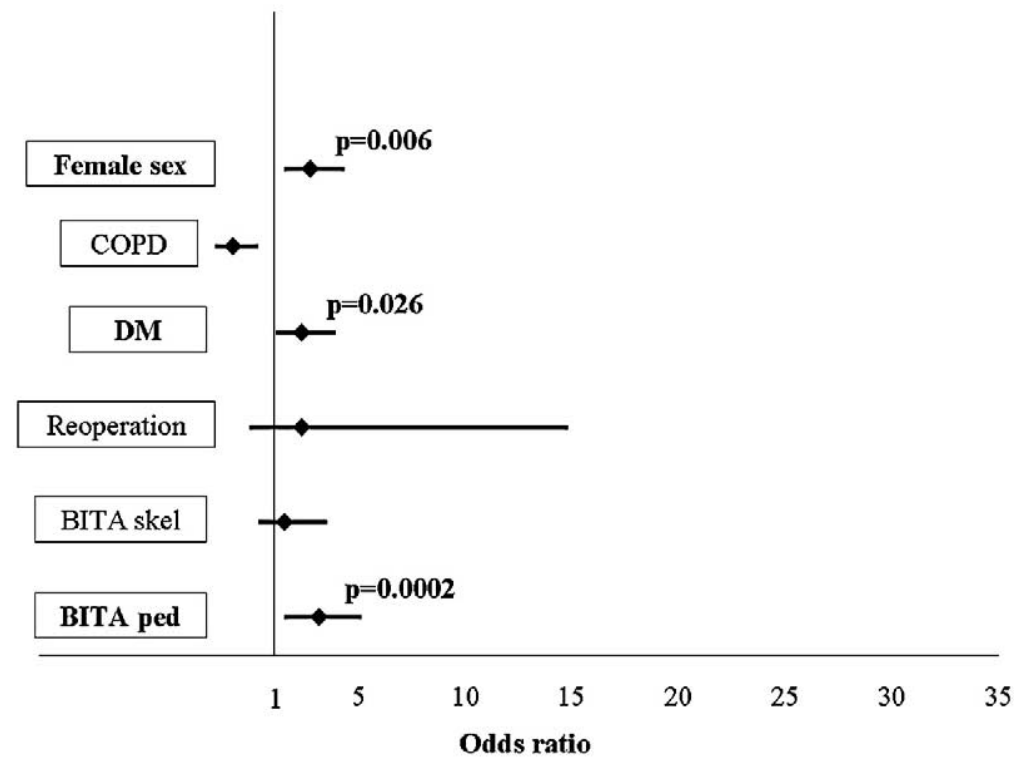

Figure 5. Odd ratios for the most significant risk factors in determining the risk of superficial sternal wound infection. COPD, Chronic obstructive pulmonary disease; DM, diabetes mellitus; BITA skel, bilateral skeletonized internal thoracic arteries; BITA ped, bilateral pedicled internal thoracic arteries.

\section{Discussion}

This study shows that the use of bilateral ITA grafting carries a significantly higher risk of sternal infection than the use of a single ITA graft. More importantly, skeletonization of bilateral ITAs significantly decreases the inci- dence of both superficial and deep sternal infection independently from most commonly known risk factors. Indeed, patients receiving skeletonized bilateral ITA conduits, despite a significantly higher prevalence of risk factors, exhibit an incidence of sternal infection significantly lower than 
those receiving pedicled bilateral ITA conduits. The results of this study support the growing perception that 2 ITAs can be used with great safety in a wide range of patients.

The use of more than 1 ITA graft has been associated with better results regarding long-term survival, reoperation, and need for angioplasty. ${ }^{1-5,21,22}$ The added benefit of BITA grafting is particularly important for the young patient population that would be otherwise faced with a higher rate of cardiac events, the need for repeat procedures, and the return of angina. Nevertheless, there is also initial evidence that BITA grafting at first operation is superior to SITA grafting in all patients up to 75 years of age. ${ }^{23}$ Furthermore, skeletonization of both ITA grafts has also been reported as a means to expand the use of ITAs, in terms of the number of anastomoses per patient, and at the same time to maintain angiographic results similar to those obtained with pedicled BITA conduits. ${ }^{16}$ As a consequence, it is increasingly more difficult do deny the benefit of bilateral ITA grafting to most patients undergoing coronary artery bypass grafting. However, given the increased risk of sternal wound dehiscence and infection associated with the use of both ITAs, many surgeons might prefer to use a single ITA conduit, especially in patients who already carry a higher risk for wound infection, such as those with diabetes, chronic obstructive pulmonary disease, obesity, peripheral vascular disease, or chronic renal insufficiency. Indeed, considering the significant increase in mortality and morbidity associated with sternal infection, ${ }^{10}$ a surgical approach that limits the degree of sternal ischemia seems justified. However, in an attempt to give patients the full benefit of bilateral ITA grafting and, at the same time, to preserve a certain degree of sternal blood flow, ITA skeletonization has progressively gained popularity. ${ }^{13,14}$ In fact, skeletonization of the ITA grafts seems to preserve substantial collateral flow to the sternum by sparing some of the sternal and intercostal branches that arise from the ITA as a common trunk. ${ }^{24,25}$

Recent articles report that skeletonization of both ITA grafts decreases the risk of sternal infection in diabetic patients ${ }^{18}$ and at the same time guarantees favorable shortand long-term cardiac outcome. ${ }^{19}$ Similar to the study of Peterson and colleagues, ${ }^{18}$ our study, which included a relatively larger number of diabetic patients (131 received BITA grafting [72 pedicled and 59 skeletonized], and 124 received SITA grafting), also confirmed the benefit of internal artery skeletonization in this high-risk subgroup of patients. In fact, among diabetic patients, the incidence of deep sternal infection was similar between patients who received SITA and those who received double skeletonized arteries (Figure 3). It is noteworthy that patients who received double pedicled arteries had a strikingly higher incidence of deep sternal infection $(9 / 72 ; 12.5 \%)$; this was very similar to the $11.1 \%$ infection rate reported by Peterson and colleagues. ${ }^{18}$ Very importantly, when diabetic patients were compared with the nondiabetic population, there were no differences among patients receiving single or bilateral skeletonized arteries, whereas there was a striking difference $(2.2 \%$ vs $12.5 \% ; P=.001)$ among those receiving bilateral pedicled conduits (Figure 3). This confirms the hypothesis that the benefit of conduit skeletonization is likely in the high-risk population. However, in patients with 2 or more risk factors, a more conservative approach can still be justified because the chance of a sternal infection increases exponentially in the presence of multiple risk factors. As an example, our diabetic patients with chronic obstructive pulmonary disease, peripheral arteriopathy, and a body mass index greater than $30 \mathrm{~kg} / \mathrm{m}^{2}$ had a rate of deep sternal infection of $28 \%$, compared with $2.3 \%$ in patients without these risk factors. Of note, independently from the harvesting technique, in a low-risk population such as nonobese, nondiabetic male patients, the rate of a deep sternal infection was $2.5 \%$ for BITA patients and $0.8 \%$ in SITA patients.

Another important findings of this study is that reexploration for bleeding is an independent and powerful risk factor (more than a ninefold increase) for deep sternal infection. The reason lies in the added tissue injury and ischemia at a time when sternal blood flow is most critical for early healing and consequent sternal stabilization. ${ }^{8,10,26,27}$ In fact, exploration for excessive postoperative bleeding ( $>200 \mathrm{~mL} / \mathrm{h}$ for 4 hours) more than 6 to 7 hours after chest closure has been shown to carry a significantly higher incidence of wound dehiscence and infection. ${ }^{28,29}$ It is therefore not surprising that avoiding re-exploration is even more critical in patients receiving bilateral ITA grafting who already have a greater acute reduction in sternal blood flow.

Another important aspect that arises from our data is that independently from a higher sternal infection rate in patients receiving bilateral ITA grafting, the overall mortality did not differ from that in patients receiving a single ITA graft. This finding and the significant reduction in sternal infection that can be obtained by skeletonizing both arterial conduits allow a more liberal and safe use of both conduits on the great majority of patients undergoing coronary artery bypass grafting.

Some concerns have been raised about the possibility that the technique of artery skeletonization might somehow damage the endothelium of the harvested ITA and consequently impair its long-term patency. Although studies are lacking on the long-term follow-up of patency and outcome after artery skeletonization, a recent review of the available literature $^{30}$ on this subject did not report any substantial evidence that skeletonization causes damage to the harvested ITAs or that the levels of patency were different from those of patients receiving pedicled ITAs. 


\section{Limitations of the Study}

Patients who received skeletonized BITAs had higher risk factors compared with the entire patient population, and this could be considered a potential selection bias. However, if anything, it could also strengthen our finding that bilateral skeletonization of ITAs could be safely extended to a larger group of patients. Furthermore, the lack of statistical significance in the rate of deep sternal wound infection among diabetic patients with SITA or skeletonized BITA might reflect inadequate statistical power. Unfortunately, the low incidence of sternal infection would have required a very large number of diabetic patients for analysis. Nevertheless, the striking difference in the rate of wound problems between these 2 subgroups and the subgroup of diabetic patients receiving pedicled BITA still underlines the intrinsic benefit of the technique of artery harvesting. Finally, our study carries all the potential limitations that are usually present in retrospective nonrandomized studies, and large randomized trials are warranted to confirm our findings.

\section{Conclusion}

Skeletonizing both ITA conduits does not completely avoid the problem of sternal infection and does not completely achieve the same results in terms of wound infection as those obtained when a single thoracic artery is used. Nevertheless, this technique of ITA harvesting considerably increases the number of patients that can be accepted for a strategy of bilateral ITA grafting by including a significant percentage of patients with diabetes and other known risk factors. However, it is still advisable not to use both ITA grafts in patients with multiple risk factors, and it is even more important to prevent postoperative bleeding in patients receiving bilateral ITA grafting, because sternal re-exploration greatly increases the risk of wound problems.

\section{References}

1. Lytle BW, Blackstone EH, Loop FD, Houghtaling PL, Arnold JH, Akhrass R, et al. Two internal thoracic artery grafts are better than one. J Thorac Cardiovasc Surg. 1999;117:855-72.

2. Endo M, Nishida H, Tomizawa Y, Kasanuki H. Benefit of bilateral IMA grafts over single IMA graft for multiple coronary artery bypass grafting. Circulation. 2001;104:2164-70.

3. Buxton BF, Komeda M, Fuller JA, Gordon I. Bilateral internal thoracic artery grafting may improve outcome of coronary artery surgery. Risk-adjusted survival. Circulation. 1998;98(suppl 2):1-6.

4. Stevens LM, Carrier M, Perrault LP, Hebert Y, Cartier R, Bouchard D, et al. Single versus bilateral internal thoracic artery grafts with concomitant saphenous vein grafts for multivessel coronary artery bypass grafting: effects on mortality and event-free survival. J Thorac Cardiovasc Surg. 2004;127:1408-15.

5. Berreklouw E, Rademakers PPC, Koster JM, van Leur L, van der Wielen BJW, Westers P. Better ischemic event-free survival after two internal thoracic artery grafts: 13 years of follow-up. Ann Thorac Surg. 2001;72:1535-41.
6. Arnold M. The surgical anatomy of sternal blood supply. J Thorac Cardiovasc Surg. 1972;64:596-620.

7. Seyfer AE, Shriver CD, Miller TR, Graeber GM. Sternal blood flow after median sternotomy and mobilization of the internal mammary arteries. Surgery. 1988;104:899-904.

8. Ottino G, De Paulis R, Pansini S, Rocca G, Tallone MV, Comoglio C, et al. Major sternal wound infection after open-heart surgery: a multivariate analysis of risk factors in 2,579 consecutive operative procedures. Ann Thorac Surg. 1987;44:173-9.

9. Kouchoukos NT, Wareing TH, Murphy SF, Pelate C, Marshall WG Jr. Risks of bilateral internal mammary artery bypass grafting. Ann Thorac Surg. 1990;49:210-9.

10. Loop FD, Lytle BW, Cosgrove DM, Mahfood S, McHerny MC, Goormastic M, et al. Sternal wound complication after isolated coronary artery bypass grafting: early and late mortality, morbidity and cost of care. Ann Thorac Surg. 1990;49:179-87.

11. Grossi EA, Esposito R, Harris LJ, Crooke GA, Galloway AC, Colvin $\mathrm{SB}$, et al. Sternal wound infections and use of internal mammary artery grafts. J Thorac Cardiovasc Surg. 1991;102:342-7.

12. Muneretto C, Negri A, Manfredi J, Terrini A, Rodella G, Elqarra S, et al. Safety and usefulness of composite grafts for total arterial myocardial revascularization: a prospective randomized evaluation. $J$ Thorac Cardiovasc Surg. 2003;125:826-35.

13. Parish MA, Asai T, Grossi EH, Esposito R, Galloway AC, Colvin SB, et al. The effects of different techniques of internal mammary artery harvesting on sternal blood flow. J Thorac Cardiovasc Surg. 1992; 104:1303-7.

14. Cohen AJ, Lockman J, Lorberboyn M, Bder O, Cohen N, Medalion B, et al. Assessment of sternal vascularity with single photon emission computed tomography after harvesting of the internal thoracic artery. J Thorac Cardiovasc Surg. 1999;118:496-502.

15. Galbut DL, Traad EA, Dorman NJ, Dewitt PL, Larsen PB, Kurlansky PA, et al. Seventeen years of experience with bilateral mammary artery grafts. Ann Thorac Surg. 1990;49:195-201.

16. Calafiore AM, Vitolla G, Iacò AL, Fino C, Di Giammarco G, Marchesani F, et al. Bilateral internal mammary artery grafting: midterm results of pedicled versus skeletonized conduits. Ann Thorac Surg. 1999;67:1637-42.

17. Matsa M, Paz Y, Gurevitch J, Shapira I, Kramer A, Pevny D, et al. Bilateral skeletonized internal thoracic artery grafts in patients with diabetes mellitus. J Thorac Cardiovasc Surg. 2001;121:668-74.

18. Peterson MD, Borger MA, Rao V, Peniston CM, Feindel CM. Skeletonization of bilateral internal thoracic artery grafts lowers the risk of sternal infection in patients with diabetes. J Thorac Cardiovasc Surg. 2003;126:1314-9.

19. Lev-Ran O, Mohr R, Pevni D, Nesher N, Weissman Y, Loberman D, et al. Bilateral internal thoracic artery grafting in diabetic patients: short-term and long-term results of a 515-patient series. J Thorac Cardiovasc Surg. 2004;127:1145-50.

20. Mangram AJ, Horan TC, Pearson ML, Silver LC, Jarvis WR. Guideline for prevention of surgical site infection, 1999. Hospital Infection Control Practices Advisory Committee. Infect Control Hosp Epidemiol. 1999;20:250-78.

21. Taggart DP, D'Amico R, Altman DG. Effect of arterial revascularization on survival: a systematic review of studies comparing bilateral and single internal mammary arteries. Lancet. 2001;358:870-5.

22. Rizzoli G, Schiavon L, Bellini P. Does the use of bilateral internal mammary artery (IMA) grafts provide incremental benefit relative to the use of a single IMA graft? A meta-analysis approach. Eur J Cardiothorac Surg. 2002;22:781-6.

23. Calafiore AM, Di Giammarco G, Teodori G, Di Mauro M, Iacò AL, Bivona A, et al. Late results of first myocardial revascularization in multiple vessel disease: single versus bilateral internal mammary artery with or without saphenous vein grafts. Eur J Cardiothorac Surg. 2004;26:542-8.

24. Henriquez-Pino JA, Gomes WJ, Prate JC, Buffolo E. Surgical anatomy of the internal thoracic artery. Ann Thorac Surg. 1997;64:1041-5.

25. De Jesus RA, Acland RD. Anatomic study of the collateral blood supply of the sternum. Ann Thorac Surg. 1995;59:163-8.

26. Stoney WS, Alford WC Jr, Burrus GR, Frist RA, Thomas CS Jr. Median sternotomy dehiscence. Ann Thorac Surg. 1978;26:421-6. 
27. Lu JC, Grayson AD, Jha P, Srinivasan AK, Fabri BM. Risk factors for sternal wound infection and mid-term survival following coronary artery bypass surgery. Eur J Cardiothorac Surg. 2003;23: 943-9.

28. Talamonti MS, LoCicero J III, Hoyne WP, Sanders JH, Michaelis LL. Early reexploration for excessive postoperative bleeding lowers wound complication rates in open heart surgery. Am Surg. 1987;53:102-4.
29. Boeken U, Eisner J, Feindt P, Petzold TH, Schulte HD, Gams E. Does the time of resternotomy for bleeding have any influence on the incidence of sternal infections, septic courses or further complications? Thorac Cardiovasc Surg. 2001;49:45-8.

30. Athanasiou T, Crossman MC, Asimakopoulos G, Cherian A, Weerasinghe A, Glenville B, et al. Should the internal thoracic artery be skeletonized? Ann Thorac Surg. 2004;77:2238-46.

\section{ON THE MOVE?}

\section{Send us your new address at least six weeks ahead}

Don't miss a single issue of the journal! To ensure prompt service when you change your address, please photocopy and complete the form below.

Please send your change of address notification at least six weeks before your move to ensure continued service. We regret we cannot guarantee replacement of issues missed due to late notification.

\section{JOURNAL TITLE:}

Fill in the title of the journal here.

\section{OLD ADDRESS:}

Affix the address label from a recent issue of the journal here.

\section{COPY AND MAIL THIS FORM TO:}

Elsevier Inc.

Subscription Customer Service

6277 Sea Harbor Dr

Orlando, FL 32887

\section{NEW ADDRESS:}

Clearly print your new address here.

Name

Address

City/State/ZIP 